\title{
Primary myoepithelial carcinoma of the lung: a rare entity treated with parenchymal sparing resection
}

\author{
Inderpal S Sarkaria ${ }^{1 *}$, Deborah DeLair ${ }^{2}$, William D Travis ${ }^{2}$, Raja M Flores ${ }^{3}$
}

\begin{abstract}
Primary lung myoepithelial carcinomas are rare neoplasms arising from the salivary glands of the respiratory epithelium. Given the rare occurrences and reports of these tumors, appropriate recommendations for resection are difficult to formulate. Although classified as low-grade neoplasms, these tumors have a significant rate of recurrence and distant metastasis.
\end{abstract}

\section{Introduction}

Primary salivary gland-type tumors of the lung are rare and include mucoepidermoid carcinoma, adenoid cystic carcinoma, acinic cell carcinoma, oncocytoma, epithelial-myoepithelial carcinoma, benign myoepithelioma, and mixed tumors of both benign and malignant nature [1-16]. Primary pulmonary myoepithelial carcinomas are exceedingly rare, with only five known prior cases reported in the English literature to date [17-20]. We report a case of primary myoepithelial carcinoma of the lung and a review of the literature.

\section{Case Report}

A 63-year-old woman presented to the clinic with a history of increasing pulmonary congestion, difficulty expectorating, and low-grade hemoptysis. Her past medical history was significant for diet-controlled insulindependent diabetes mellitus. There was no history of cigarette or other tobacco use. Her mother had died of breast cancer in her fifties. A chest radiograph showed a large mass in the right lower lung fields, and computed tomography scanning revealed a $12.4 \times 8.3$ centimeter smoothly circumscribed heterogeneous mass arising in the right minor fissure and impinging upon the right atrium (Figure 1A). A fine needle aspiration was performed which yielded a diagnosis initially suspicious for schwannoma, as reviewed at an outside institution. At

\footnotetext{
* Correspondence: sarkaril@mskcc.org

${ }^{1}$ Department of Surgery, Thoracic Service, Memorial Sloan-Kettering Cancer Center, 1275 York Avenue, New York, NY, 10065, USA

Full list of author information is available at the end of the article
}

the time of thoracotomy, dense adhesions were dissected free of the upper and middle lobes with no evidence of tumor invasion, and the mass was resected en-bloc with pericardium and a wedge resection of the lower lobe. An additional separate lower lobe nodule was also excised and presumed to be a metastatic focus of tumor. The patient had an uneventful recovery and was discharged home on post-operative day number three.

The patient developed a biopsy proven solitary liver/ diaphragmatic metastasis diagnosed on routine followup at 36 months post-resection.

\section{Pathologic Findings}

Gross pathologic examination revealed the mass to be a $13 \times 8 \times 8$ centimeter lower lobe carcinoma of myoepithelial origin involving the visceral pleura (Figure 1B).

Histologically, the mass was consistent with a malignant myoepithelial neoplasm with a fibrous capsule and $20 \%$ necrosis. The mass was thought to arise from the right lower lobe and involved the visceral pleura. The margin was focally within $0.1 \mathrm{~cm}$ of the tumor, but otherwise grossly free of invasion. The separate nodule was $1 \mathrm{~cm}$ in size and histologically similar to the primary tumor.

Immunohistochemical stains were performed and were focally positive for AE1/AE3, Bcl2, Cam5.2, S100p, GFAP, 4A4, SMA, and CD99. Stains for EMA, desmin, CD34, calponin, FLI1, myogenin, and synaptophysin were negative.
C Biomed Central

๑ 2011 Sarkaria et al; licensee BioMed Central Ltd. This is an Open Access article distributed under the terms of the Creative Commons Attribution License (http://creativecommons.org/licenses/by/2.0), which permits unrestricted use, distribution, and reproduction in any medium, provided the original work is properly cited. 


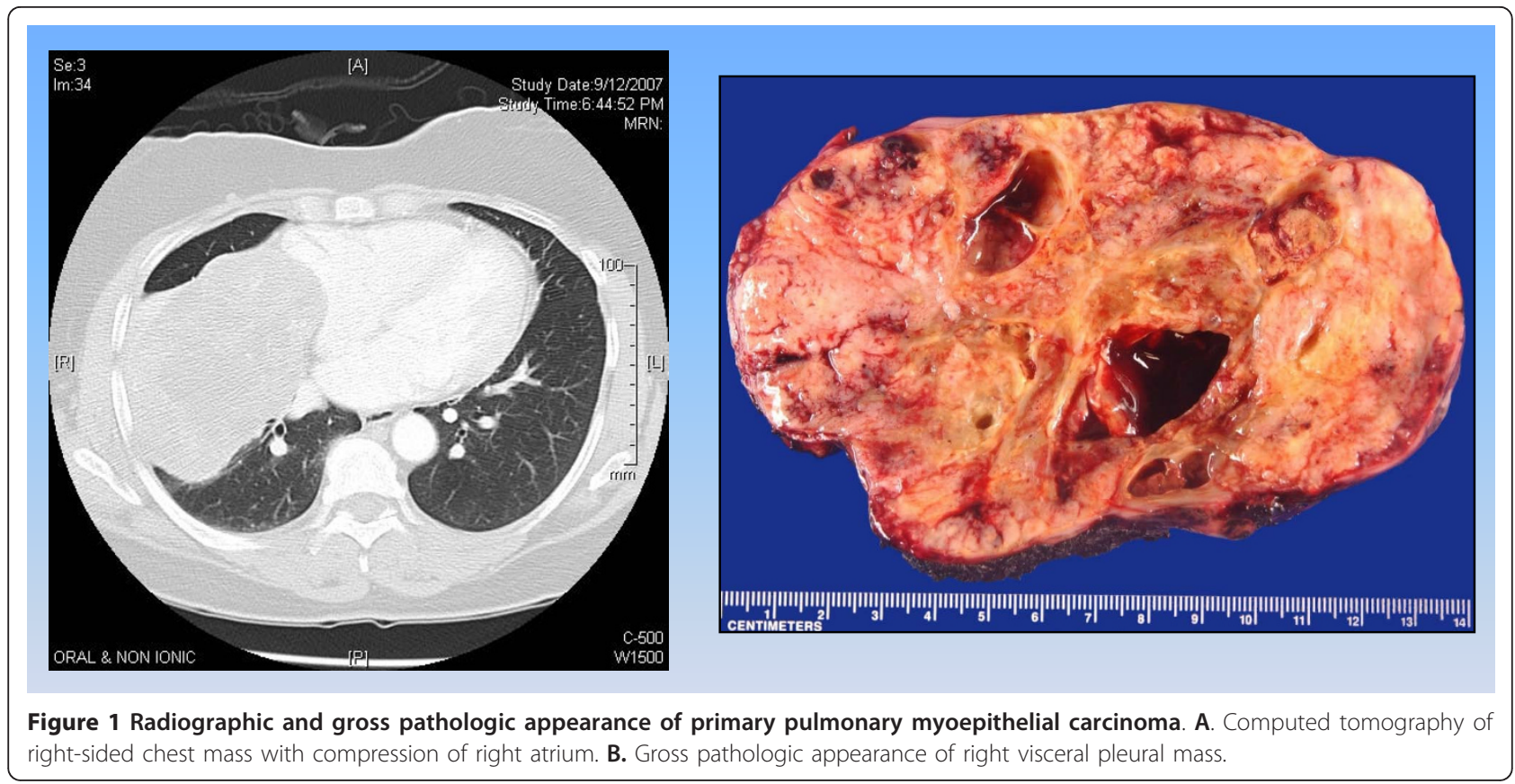

\section{Discussion}

Myoepithelial carcinomas primarily arise from the salivary glands, the parotid, or the breast [21]. Rarely, they may arise in soft tissues, most often in the lower and upper limbs, occurring equally in men and women [22]. These soft-tissue tumors, distinguished from benign myoepitheliomas by their moderate or severe cytologic atypia or invasive growth pattern, recur locally in $42 \%$ of patients and metastasize to distant sites in $32 \%$.
Primary myoepithelial carcinomas of the lung are exceedingly rare, with only 6 patients reported in the English literature, including the present report [17-20]. Clinical data from these reports are summarized in Table 1. Very limited information was available for one patient [20]. Most patients were male, in their fifth or sixth decade of life at diagnosis, and smoked tobacco. Most patients presented with primarily endobronchial disease, had preoperative biopsies of their tumors, and

Table 1 Clinical characteristics of reported cases of myoepithelial carcinoma of the lung

\begin{tabular}{|c|c|c|c|c|c|c|c|c|c|}
\hline AUTHOR & $\begin{array}{l}\text { Age/ } \\
\text { Sex }\end{array}$ & Smoking & Location & $\begin{array}{l}\text { Pre-op Bx } \\
\text { Diagnosis }\end{array}$ & $\begin{array}{l}\text { Size } \\
(\mathrm{cm})\end{array}$ & Resection Type & $\begin{array}{l}\text { Local } \\
\text { Recurrence }\end{array}$ & Metastasis & Outcome \\
\hline Present case & $63 \mathrm{~F}$ & No & $\begin{array}{l}\text { RLL, Pleural \& } \\
\text { parenchymal }\end{array}$ & $\begin{array}{l}\text { Low grade } \\
\text { spindle cell } \\
\text { neoplasm }\end{array}$ & 13.0 & $\begin{array}{l}\text { Wedge/Local } \\
\text { excision }\end{array}$ & No & $\begin{array}{l}\text { Yes, same lobe/ } \\
\text { pleura at time of } \\
\text { resection, liver at } 36 \\
\text { months }\end{array}$ & AWD at 36 months \\
\hline Masuya 2005 & $48 \mathrm{M}$ & Yes & $\begin{array}{l}\text { LLL, } \\
\text { Parenchymal } \\
\& \\
\text { Endobronchial }\end{array}$ & $\begin{array}{l}\text { Sarcoma, } \\
\text { sarcomatoid } \\
\text { carcinoma, } \\
\text { carcinosarcoma }\end{array}$ & 1.5 & Lobectomy & No & No & NED 15 months \\
\hline Miura 2000 & $46 \mathrm{M}$ & NA & $\begin{array}{l}\text { Right hilum, } \\
\text { Right Main } \\
\text { Stem, } \\
\text { Endobronchial }\end{array}$ & $\begin{array}{l}\text { No atypical } \\
\text { cells }\end{array}$ & 6.5 & Pneumonectomy & No & Yes, LLL & AWD at 7 months \\
\hline Higashiyama & $58 \mathrm{M}$ & Yes & $\begin{array}{l}\text { RUL, } \\
\text { Endobronchial }\end{array}$ & NA & 3.8 & $\begin{array}{l}\text { Sleeve } \\
\text { bilobectomy } \\
\text { (RUL/RML) }\end{array}$ & No & $\begin{array}{l}\text { Yes, soft tissue left } \\
\text { arm and hip }\end{array}$ & $\begin{array}{l}\text { DOC at } 14 \text { months } \\
\text { (metastatic } \\
\text { synchronous } \\
\text { adenocarcinoma) }\end{array}$ \\
\hline $\begin{array}{l}\text { Higashiyama } \\
1998\end{array}$ & $58 \mathrm{M}$ & Yes & $\begin{array}{l}\text { LUL, } \\
\text { Endobronchial }\end{array}$ & $\begin{array}{l}\text { Squamous cell } \\
\text { carcinoma }\end{array}$ & 6.0 & $\begin{array}{l}\text { Sleeve } \\
\text { lobectomy (LUL) }\end{array}$ & No & Yes, liver & DOD, 60 months \\
\hline Sekine 1998 & NA & NA & NA & NA & NA & NA & NA & Yes & NA \\
\hline
\end{tabular}

RLL - right lower lobe; LLL - left lower lobe; RUL - right upper lobe; LUL - left upper lobe; RML - right middle lobe; Bx - biopsy; NED - no evidence of disease; AWD - alive with disease; DOC - dead of other causes; DOD - dead of disease. 
underwent anatomic resections of these malignancies. There were no local recurrences. Almost all patients had metastatic disease, either synchronous at time of resection, or presenting as metachronous recurrence. Follow-up was less than two years for all but one patient, who died of metastatic disease to the liver five years postoperatively. One other patient died at fourteen months from synchronous metastatic adenocarcinoma. One patient was alive with disease, and two others were free of disease at relatively short follow-up intervals.

Given the available reported data, there are a number of unique characteristics of the current case when compared to the previous five. This case represents the eldest and only female patient, as well as the only known never-smoker. This patient's tumor is also the greatest in size within this series, more than doubling the previous known largest of these tumors. All other patients in the series presented with a major component of endobronchial disease, whereas the current tumor was primarily pleural/parenchymal based. Finally, the current case represents the only patient treated with a limited sub-anatomic resection.

Given the relatively high rates of recurrence, low-grade malignant status, and the propensity for recurrence at distant sites, it is reasonable to consider limited sub-anatomic, parenchymal sparing resections for these patients, especially if pneumonectomy is contemplated. While this may not be adequate for endobronchial lesions involving major pulmonary segments, it is feasible for lesions presenting with primarily parenchymal or pleural based disease, as in the current case. Given the rarity of these tumors, recommendations regarding chemotherapy or radiation, either pre- or postoperatively, are difficult to formulate.

\section{Consent}

Written informed consent was obtained from the patient for publication of this case report and accompanying images. A copy of the written consent is available for review by the Editor-in-Chief of this journal.

\footnotetext{
Author details

'Department of Surgery, Thoracic Service, Memorial Sloan-Kettering Cancer Center, 1275 York Avenue, New York, NY, 10065, USA. ${ }^{2}$ Department of Pathology, Memorial Sloan-Kettering Cancer Center, 1275 York Avenue, New York, NY, 10065, USA. ${ }^{3}$ Division of Thoracic Surgery, Mount Sinai Medical Center, 1190 Fifth Avenue, PO Box 1028, New York, NY, 10029, USA.
}

\section{Authors' contributions}

ISS performed study design, data collection, and primary manuscript preparation and revision. DD performed gross, histological, and molecular pathology review and interpretation. WDS performed study design, pathology review, and manuscript preparation and revision. RMF performed study inception, study design, study oversight, and manuscript review and revision. All authors have read and approved the final manuscript.
Received: 21 October 2010 Accepted: 8 March 2011

Published: 8 March 2011

\section{References}

1. Doganay L, Bilgi S, Ozdil A, Yoruk Y, Altaner S, Kutlu K: Epithelialmyoepithelial carcinoma of the lung. A case report and review of the literature. Arch Pathol Lab Med 2003, 127:e177-180.

2. Cagirici U, Sayiner A, Inci I, Veral A: Myoepithelioma of the lung. Eur J Cardiothorac Surg 2000, 17:187-189.

3. Fulford LG, Kamata Y, Okudera K, Dawson A, Corrin B, Sheppard MN, Ibrahim NB, Nicholson AG: Epithelial-myoepithelial carcinomas of the bronchus. Am J Surg Pathol 2001, 25:1508-1514.

4. Cho KJ, el-Naggar AK, Ordonez NG, Luna MA, Austin J, Batsakis JG: Epithelial-myoepithelial carcinoma of salivary glands. A clinicopathologic, DNA flow cytometric, and immunohistochemical study of Ki-67 and HER-2/neu oncogene. Am J Clin Pathol 1995, 103:432-437.

5. Davis PW, Briggs JC, Seal RM, Storring FK: Benign and malignant mixed tumours of the lung. Thorax 1972, 27:657-673.

6. Fechner RE, Bentinck BR, Askew JB Jr: Acinic cell tumor of the lung. A histologic and ultrastructural study. Cancer 1972, 29:501-508.

7. Horinouchi H, Ishihara T, Kawamura M, Kato R, Kikuchi K, Kobayashi K, Maenaka Y, Torikata C: Epithelial myoepithelial tumour of the tracheal gland. J Clin Pathol 1993, 46:185-187.

8. Moran CA, Suster S, Askin FB, Koss MN: Benign and malignant salivary gland-type mixed tumors of the lung. Clinicopathologic and immunohistochemical study of eight cases. Cancer 1994, 73:2481-2490.

9. Nistal M, Garcia-Viera M, Martinez-Garcia C, Paniagua R: Epithelialmyoepithelial tumor of the bronchus. Am J Surg Pathol 1994, 18:421-425.

10. Pelosi G, Fraggetta F, Maffini F, Solli P, Cavallon A, Viale G: Pulmonary epithelial-myoepithelial tumor of unproven malignant potential: report of a case and review of the literature. Mod Pathol 2001, 14:521-526.

11. Ryska A, Kerekes Z, Hovorkova E, Barton P: Epithelial-myoepithelial carcinoma of the bronchus. Pathol Res Pract 1998, 194:431-435, discussion 436-438.

12. Santos-Briz A, Terron J, Sastre R, Romero L, Valle A: Oncocytoma of the lung. Cancer 1977, 40:1330-1336.

13. Spencer H: Bronchial mucous gland tumours. Virchows Arch A Pathol Anat Histol 1979, 383:101-115.

14. Strickler JG, Hegstrom J, Thomas MJ, Yousem SA: Myoepithelioma of the lung. Arch Pathol Lab Med 1987, 111:1082-1085.

15. Tsuji $N$, Tateishi R, Ishiguro S, Terao T, Higashiyama M: Adenomyoepithelioma of the lung. Am J Surg Pathol 1995, 19:956-962.

16. Wilson RW, Moran CA: Epithelial-myoepithelial carcinoma of the lung: immunohistochemical and ultrastructural observations and review of the literature. Hum Pathol 1997, 28:631-635.

17. Higashiyama M, Kodama K, Yokouchi H, Takami K, Kabuto T, Tsuji N, Mano M, Ishiguro S, Ueda T, Yoshikawa H, Tatsuta M: Myoepithelioma of the lung: report of two cases and review of the literature. Lung Cancer 1998, 20:47-56.

18. Masuya $\mathrm{D}$, Haba R, Huang $\mathrm{CL}$, Yokomise $\mathrm{H}$ : Myoepithelial carcinoma of the lung. Eur I Cardiothorac Surg 2005, 28:775-777.

19. Miura K, Harada H, Aiba S, Tsutsui Y: Myoepithelial carcinoma of the lung arising from bronchial submucosa. Am J Surg Pathol 2000, 24:1300-1304.

20. Sekine I, Kodama T, Yokose T, Nishiwaki Y, Suzuki K, Goto K, Nagai K, Kuriyama T: Rare pulmonary tumors - a review of 32 cases. Oncology 1998, 55:431-434.

21. Colby TV, Koss MN, Travis WD: Tumors of salivary gland type. In Atlas of tumor pathology Tumors of the lower respiratory tract. Edited by: Colby TV, Koss MN, travis WD. Washington, D.C.: Armed Forces Institute of Pathology; 1995:65-89.

22. Hornick JL, Fletcher CD: Myoepithelial tumors of soft tissue: a clinicopathologic and immunohistochemical study of 101 cases with evaluation of prognostic parameters. Am J Surg Pathol 2003, 27:1183-1196.

doi:10.1186/1749-8090-6-27

Cite this article as: Sarkaria et al: Primary myoepithelial carcinoma of the lung: a rare entity treated with parenchymal sparing resection. Journal of Cardiothoracic Surgery 2011 6:27.

\section{Competing interests}

The authors declare that they have no competing interests. 